\title{
Three years later: Italy and the free movement of new EU workers
}

UDK: $349.2 E U: 331.43(451 / 459)$

\author{
Roberta Nunin \\ Università di Trieste
}

\begin{abstract}
The freedom of movement of workers as one of the four main pillars of the EU can be defined as a neutral principle, which ensures its use in both the economic area for which it was created and also the social area. This paper focuses on Italy's response with regard to implementing this principle in the last two rounds of EU enlargement in 2004 and 2007. This rule guarantees workers freedom of movement, including the elimination of any discrimination on the basis of the nationality of workers from member states with regard to employment, pay, and other work and employment conditions.
\end{abstract}

Key words: labour law, EU workers, European regulations, European Community

1. Italian labour law scholars have repeatedly pointed out that the free movement of workers - one of the four pillars of the original European Community plan - can be defined in terms of a "neutral" principle, capable, that is, to provide applications both in the economic field, where it was first established, and in the social field, where it provides an interesting meeting point for labour issues, in the strict sense of the word, and welfare issues ${ }^{1}$.

This paper is going to look at how Italy responded to the application of such principle on the occasion of the last two Community enlargements, in 2004 and in 2007; while it appears superfluous to dwell here on the connection between free workers circulation and the creation of a supernational European entity, quite obvious anyway, it seems quite useful to recall at least the content of the free circulation right, with special attention to subordinate

1 See Tosi P. - Lunardon F., Introduzione al diritto del lavoro. 2. L'ordinamento europeo, Roma-Bari, Laterza, 2005, 101; Ghera E., Sicurezza sociale e libera circolazione dei lavoratori: principi fondamentali e soggetti, in II Diritto del lavoro, 1998, I, 121. 


\section{Roberta Nunin}

\section{Three years later: Italy and free movement of new EU workers}

workers. This right, recognized to citizens of member States by art. 39-42 of the Treaty, entails the abolition of all discrimination based on the nationality of member States workers, both for employment and working conditions, and includes the right to enter the territory of any member State in order to answer a job offer, the right of establishment and the right to keep there one's residence after finding a job.

The principle of free circulation is therefore substantiated by the provision of three fundamental guarantees: a) the ban of any discrimination based on nationality as far as employment, wages and other working conditions are concerned (except for a number of limitations gradually eased away by the Court of Justice); b) the right of establishment; $c$ ) the right to a coordinated welfare system.

On this matter, great prominence was held for nearly forty years by EEC Regulation No. 1612/1968, recently modified by Directive No. 38/2004/EC, now the reference "Consolidated Law", aimed at overcoming the fragmented and sectional character of previous regulations. The new Directive - implementing a number of indications emerged from the Court of Justice case law among other things: recognizes to all citizens of the European Union the right to establishment in the territory of another member State for a period of time no longer than three months without any formal procedure, except holding a valid identity card or passport (this right also applies to non-European relatives who may accompany or join the European citizen, as long as they hold a valid passport and entry visa); cancels the requirement for a residence permit; recognizes to the worker's relatives a personal right to establishment (for instance in case of marriage dissolution); recognizes the right of permanent and unconditional establishment for the European citizen after 5 years of enjoying such right. The right to establishment for a period of time longer than three months is subject to the following conditions: being engaged in employed or selfemployed work; having adequate economic resources (corresponding to a minimum state pension: art. 8, § 4 of the 2004 Directive), as well as a health insurance; being enrolled at a public or private institution to follow a course of study or professional training while holding a health insurance and having adequate economic resources; being a relative who accompanies or joins a European citizen meeting one of the above mentioned three conditions. The meaning of "relative" is given by the directive mentioning to that end not only the spouse, but also a partner who contracted with the European citizen a union registered by the law of a member state, if the host state law equates a 
registered union with marriage, and in compliance with the conditions provided for by the host member state. Relatives are also considered all direct descendants less than 21 years of age or dependent children (and the spouse or partner's ones), as well as any dependent direct ascendant (and the spouse's or partner's). It is interesting to note that the Directive also applies to other family figures - such as a "de facto" spouse or those persons who are dependent or cohabiting in the country of origin or must be looked after for health reasons if the host State, according to its own national law and following an in depth examination deems appropriate not to deny entry.

Even after the latest amendments, we still find in the Treaty titles devoted to the free movement of subordinate workers (art. 39-42: free circulation of workers), of non-subordinate workers who want to move definitely and permanently (art. 43-48: right to establishment), and self-employed workers who want to move temporarily in order to carry out self-employed work (art. 49-55: freedom to supply services).

We shall only deal here with the first ones.

If at the end of the Fifties European regulations were designed mostly to allow Italian workers to migrate to the other five member Countries, during the years and then decades such regulations have remained unchanged, but the migratory flows have considerably changed. Lastly, the enlargement to the East of the European Community, together with the growth of non-European immigration, has highlighted a general problem of control of migratory flows in Europe, both from the point of view of social integration and of cultural integration $^{2}$.

The tensions triggered off in many Countries by a significant growth of migratory flows certainly explain the resistances that led many of the old member states - among which, at first, also Italy - to adopt the much debated "moratorium", we shall cover more in detail later. Certainly, as it was pointed out recently, the principle of free movement of workers still is a central and crucial chapter of European labour law $\mathbf{3}^{\mathbf{3}}$ : central, because it identifies one of the fundamental rights of European citizens, confirmed as such today by the constitutional Treaty (see art. I-4 and II-75) and can be a useful point of reference in view of adopting instruments to control migratory trends that may come to include Third Countries citizens; crucial, because we cannot ignore the problems and tensions that a straightforward application of such principle

2 See Brollo M., Immigrazione e libertà di circolazione, in II Lavoro nella giurisprudenza, 2006, 1069, 1074.

3 See Brollo M., Ibidem. 


\section{Roberta Nunin}

\section{Three years later: Italy and free movement of new EU workers}

could spark off on individual national labour markets, should the group of European partners show increasingly marked diversifications, with the risk of giving rise to phenomena of significant social dumping ${ }^{\mathbf{4}}$.

In other words, whether rightly or wrongly, the "Polish plumber syndrome" spread even within part of the "old" member States' public opinion; that was joined by a sort of "nostalgia" for the old exclusive "club" of a pre-enlargement European Community", echoed by the sensational rejection of the constitutional Treaty by two EEC founding members, France and the Netherlands.

Three years later, we can actually say that the fears of a massive invasion - at least by looking at the Italian situation - turned out to be unfounded, and indeed several new member Countries appear to be worried about having to check the flight temptations of their more qualified workforce while, at the same time, confronting problems caused by their demographic profile which is getting closer to ours, with low birth rates and an expected growing old age population.

2. While the Treaty shows a marked distinction between subordinate workers and self-employed workers mobility, it does not provide a specific definition for the two different figures.

The Court of Justice however took care of that, with a rich jurisprudential output $^{\mathbf{6}}$, starting back in the Sixties, and gradually defining not only the limits of the "European level" concept of subordinate worker, but looking also more in depth at the rights involved as well as the scope of limitations to the freedom of circulation.

4 About levels of wages in old and new member States, see Schulten T., Minimum wages in Europe, in Transfer-European Review of Labour and Research, 2006, 2, 277; Schulten T., Bispinck R., Schäfer C. (eds.), Minimum wages in Europe, Brussels, ETUI, 2006.

5 See Padoa-Schioppa T., L'Europa della malinconia, lecture held at University Bocconi of Milan, Inauguration of academic year 2005/2006; see also Traser J., Who's still afraid of EU enlargement?, Report on the free movement of workers in EU-25, 2006, www.ecas.org.

6 See Blanpain R., European Labour Law, The Hague, Kluwer Law Int. (30 ${ }^{\text {th }}$ ed.), 2006, 284; Galantino L., Diritto comunitario del lavoro, Torino, Giappichelli, 2005, 85; Roccella M.- Treu T., Diritto del lavoro della Comunità europea, Padova, Cedam, 2002; Foglia R., L'applicazione giurisprudenziale del regolamento CEE n. 1408/71, in II Diritto del lavoro, 1999, II, 138; Arrigo G., Il diritto del lavoro dell'Unione Europea, vol. I, Milano, Giuffrè, 1998, 227; Nascimbene B., La libera circolazione dei lavoratori, Milano, Giuffrè, 1998; Giubboni S., Libertà di circolazione e protezione sociale nell'Unione Europea, in Giornale di Diritto del lavoro e relazioni industriali, 1998, 1, 81; Roccella M., L'Europa e L'Italia: libera circolazione dei lavoratori e parità di trattamento trent'anni dopo, in Rivista Giuridica del lavoro e della previdenza sociale, 1997, I, 279; Id., La Corte di Giustizia ed il diritto del lavoro, Torino, Giappichelli, 1997. 


\section{Three years later: Italy and free movement of new EU workers}

On this jurisprudential work we must now, somehow quickly, expand.

Beginning at the end of the Sixties, the Court of Justice engaged in the elaboration of a "European" concept of subordinate worker, with the aim to prevent member States from limiting access to subordinate work, in line with a "protectionist" view, for European workers from other Countries".

This is in any case a concept elaborated on the basis of common fundamental principles, and from the point of view of Italian law and in an Italian perspective, structured on tenets basically accepted also by the Italian national law ${ }^{\mathbf{8}}$. In essence, subordinate worker is assumed to be anyone who carries out, in a position of subordination with regard to another subject and in exchange for a fee, a work activity that - even when showing a reduced commitment - is genuine and effective and not such as to be regarded as purely marginal and ancillary. In such a wide perspective, the Court jurisprudence has judged as included in the protection range, for example, all subordinate workers working for employers who are not companies, those who are engaged in work relationships that are atypical or in any case characterized by special feature with respect to the "standard" model, like fixed-term workers, temporary workers, part-time workers, home workers, workers employed with training contracts (apprenticeship and educational contracts of various denominations, etc.), domestic workers, sports workers ${ }^{9}$. Moreover, the Court of Justice pointed out that the presence of subordination is not incompatible with the existence of family bonds (as for example in the case of marriage with the director and sole shareholder of the employing company $)^{\mathbf{1 0}}$. The objective of the Court of Justice was to grant maximum efficacy to the principle of free circulation, preventing member countries from elaborating as many concepts of subordinate worker as there are juridical systems.

We already talked about the "contents" of the freedom of movement of workers and we will therefore add just a few details here.

7 Among the many rulings I shall only mention, of the most significant ones, CoJ 19 March 1974, C-75/63, Unger; CoJ 23 March 1982, C-53/81, Levin; CoJ 3 July 1986, C-66/85, LawrieBlum; CoJ 12 May 1998, C-85/96, Martinez Sala; among the most recent ones, see CoJ 23 March 2004, C-138/02, Collins.

8 Galantino L., Diritto comunitario, op. cit., 92.

9 As for the latter I shall just mention in passing the very famous Bosman ruling dated 15 December 1995 (C-415/93) on professional football, and Lehtonen, dated 13 April 2000 (C176/96), on professional basketball players, confirming that sports work also falls under the scope of application of art. 48 of the Treaty if it is carried out in subordinate role, i.e. on a continuous basis and after payment.

10 See CoJ 18.06.1999, C-337/97, Meeusen. 


\section{Roberta Nunin}

\section{Three years later: Italy and free movement of new EU workers}

On the subject of access to work, art. 39 TCE ensures the right to answer genuine job offers and the right to move freely for that purpose in the territory of member States, without specifying whether the worker must have found a job already before leaving. The Court jurisprudence has actually pointed out that the Treaty provision must be interpreted extensively, meaning that it includes the right to stay in a member State even to look for a job, for a reasonable length of time, so as to allow European citizens to get to know the work conditions in the host Country (see CoJ 26 February 1991, Antonissen, taking such period of time to be six months); the principle has now been established in the 2004 directive, although with a three month term for a stay without conditions (unless that does not become a too great burden for the member Country welfare system); when this period expires, if the person has not found a job he must show to have adequate resources and a health insurance; however, even in the absence of the above conditions, and following an indication of the Court of Justice ${ }^{\mathbf{1 1}}$, the 2004 directive now rules under art. 14 that a European citizen who can demonstrate he is looking for a job and has a good chance to find it cannot be asked to leave the host Country. Access to work is ensured at the same conditions applied to native workers and with preference given in respect of non-European workers. Member States are required to remove any legal provision or administrative practice that may impose restrictions, directly or indirectly. Special attention was granted by the Court to indirect discrimination: such as, for example, the failed recognition of merits or qualifications acquired by the candidate according to the law in force in his country of origin ${ }^{\mathbf{1 2}}$. I shall not however dwell here on the complex theme of mutual recognition of qualifications and diplomas, covered in the European community by a complex network of general and sector specific rules.

As for equal treatment, that applies not only to working conditions, but also to trade unions membership and the exercise of union rights, as well as social advantages, including access to housing and home ownership (e.g. the recent CoJ 12.5.98, Martinez Sala, considering as a social advantage the education indemnity aimed at compensating the recipient's family expenses). The

11 See Antonissen, 26 February 1991, C-292/89; Commission vs. Belgium, 20 February 1997, C- 344/95.

12 See CoJ 23 February 1994, C-419/92, Scholz. 


\section{Roberta Nunin \\ Roberta Nunin
w EU workers}

ban applies not just to overt discriminations based on citizenship ${ }^{\mathbf{1 3}}$, but also indirect or disguised ones ${ }^{\mathbf{1 4}}$.

At the end of the work relationship, the migrant worker (now unemployed) can continue to enjoy a number of rights connected with worker status (reinstatement, outplacement, professional training). The Court of Justice also rules that the status is maintained also as regards social and tax advantages, as long as the unemployed worker is in touch with the labour market, i.e. he continues to actively look for a job ${ }^{\mathbf{1 5}}$.

Art. 39 moreover recognizes the right to remain on a member State territory after having been employed there, at the conditions provided for by the applying regulations ${ }^{\mathbf{1 6}}$.

Lastly, we must mention the exceptions provided for to the freedom of circulation: they are just three, and refer to public policy, public security and public health issues, respectively, with a few specific regulations added on the subject of access to public employment.

As regards public policy and public security issues, the 2004 directive confirmed a series of principles already elaborated by the Court of Justice case law: 1) although the definition of public policy is left to member States discretion, in the European context it must be interpreted in the strict sense of the word; personal behaviour can cause disturbances in public order when it is a real threat, serious enough to compromise one of society fundamental interests (see CoJ 19 January 1999, Calfa; CoJ 4 December 1974, Van Duyn); 2) the measures taken cannot automatically rest on criminal sentences (CoJ 26 November 2002, Olazabal); 3) the reasons given to adopt such measures must be brought to the knowledge of the party involved, who must be able to rely

13 See CoJ 30 November 2000, C-195/98, Osterreichischer Gewerkschaftsbund, according to which freedom of circulation is hindered by a law - in this case Austrian - that, in working out teachers salaries, calculates the periods of previous activity differently, depending on whether such activity was carried out in Austria or in other member States.

14 For example, in assigning extra points for pension calculations in case of early retirement only to residents and not to cross-border workers: see CoJ 26 January 1999, C-18/95, Terho$v e$; see also the complex and troubled Italian affair of foreign language lectors, providing for ad hoc time limits in contract duration: see CoJ 2 August 1993, C-259/91, C-331/91 and C332/91, Alluè et al.; CoJ 26 June 2001, C-212/99, Commission vs. Repubblica Italiana.

15 See, among the most recent rulings, CoJ 6 November 2003, C-413/01, Ninni-Orasche; "subordinate worker" cannot however be considered any person who carried out a work activity as far as 17 years before: CoJ 23 April 2004, Collins.

16 See reg. 1251/70, stating that workers who have become disabled, cross-border workers and whoever qualifies for old age and invalidity pension have the right to remain permanently in the member State where they carried out a work activity for a minimum period of time - different according to the listed categories - and as long as they reside in the host country for a certain number of years, again different according to each category. 


\section{Roberta Nunin}

\section{Three years later: Italy and free movement of new EU workers}

on instruments of jurisdictional and, if necessary, administrative protection, at the same conditions enjoyed by the member State citizens.

As regards public health issues, dir. No. 2004/38 states that any measure restricting the freedom of circulation is justified only in the case of potentially epidemic diseases, as defined by the World Health Organization.

Lastly, as regards public employment, the Court of Justice gave a European definition of public employment - aimed at preventing any action of a protectionist nature by member Countries - indicating as public employment any type of job that implies a direct or indirect participation to the exercise of public power and duties, dealing with the protection of the State general interests or other public communities and implying therefore, for whoever holds it, a special relationship of solidarity with the State ${ }^{\mathbf{1 7}}$.

3. As already happened in the previous European Community enlargements, the 1 May 2004 one $^{\mathbf{1 8}}$ gave existing member Countries the right to avail themselves of a period of transitional regime in connection with the general right to the freedom of circulation, establishment and residence on their territory for subordinate workers who were citizens of new member Countries.

Of the "old" members, most of them (excluding the UK, Ireland and Sweden) decided at the beginning to adopt the moratorium for eight of the new 2004 members (Maltese and Cypriot citizens, on the other hand, were immediately able to enjoy the freedom of movement). Such a "protectionist" choice, strongly supported in particular by Austria and Germany, due to geographical proximity and fear for possible labour market problems, also registered full consensus on the part of Italy, while France opted for a "selective"

17 The Court of Justice thus denied, for example, the legitimacy of limitations applied to health care personnel in public employment (see Commission vs. France, 3 June 1986, C$307 / 84$ ) or, quite recently in an Italian case, for security guards (see Commission vs. Italy, 31 May 2001, C-283/99).

18 Which involved Estonia, Latvia, Lithuania, Poland, Czech Republic, Slovak Republic, Slovenia, Hungary, Malta e Cyprus. About the application of the moratorium period by Italy, see Gazzetta C., La circolazione finalmente libera dei lavoratori neocomunitari, in II Lavoro nella giurisprudenza, 2006, 8, 729; Brollo M., Immigrazione e libertà di circolazione, cit. Looking at the impact of enlargement on national labour markets, see the papers presented by $F$. Carinci (Italy), A. Athanasiu (Romania), H. Barancova (Slovak Republic), R. Birk (Germany), M. Brollo (Italy), T. Davulis (Lithuania), L. Dux (Hungary), L. Florek (Poland), D. Garofalo (Italy), J. Hajdù (Hungary), P. Koncar (Slovenia), M. Löwish (Germany), L. Menghini (Italy), M. Miscione (Italy), T. Tomandl (Austria), K. Tomashevski (Belarus), Z. Vodovnik (Slovenia), A. Voitik (Belarus), I. Vukorepa (Croatia) at the International Congress "Il lavoro nell'Europa che cambia" (Udine, 19 September 2005), now published in Transition Studies Review, 2006, 1, 3-77. 


\section{Three years later: Italy and free movement of new EU workers}

moratorium. Later, Finland, Greece, Portugal and Spain opted for a nonprotectionist stance, joined by Italy on 1 January 2007, following the Italian Council of Ministers decision dated 21 July 2006.

The transitional regime - to be divided into three time periods (two years - three years - two years) - is regulated by a set of clauses contained in an enclosure of the Accession Treaty for the ten new 2004 member Countries. ${ }^{\mathbf{1 9}}$ The transition period division into three different phases was provided for in order to allay the fears of some member Countries about the impact on their labour market of such a conspicuous enlargement, to achieve in a soft and gradual way the full application of Community regulations on the subject of freedom of circulation; it acknowledged in the first place the possibility to delay its full application by two years (during which control of entry for new EU subordinate workers would be left to each country national legal system). At the end of such period, on 30 April 2006, any State that wished to delay by another three years the application of European law had to notify its choice to the Commission (for Italy that was done by the Berlusconi Government, with a decision later repudiated by the Prodi Government, following the change in government majority - from centre-right to centre-left - after the general election held in Italy during the spring of 2006) as without such notification the freedom of circulation law would automatically have been enforced. After 30 April 2009, it will be possible to extend the moratorium by no more than two years, and only when the State concerned presents some objective reasons (i.e. if there were serious problems registered in its labour market or there is a risk of that happening). In any case, the total duration of the transitional period will not be allowed to exceed ten years (that is until 30 April 2011).

As we come to analyze the legal aspects and critical conditions connected with the initial choice made by Italy to avail itself of the moratorium - any consideration made here shall also apply obviously to the last 2007 enlargement - it must be pointed out first that in any case, even with the choice of a moratorium, all Countries are subject to the operational nature of the "stand still" clause, according to which the conditions for labour market access to new EU citizens, although restrictive, cannot be more so than those in force before the Accession Treaty signing date. Another general clause pertains to the preference given to new EU workers, to whom is guaranteed priority over Third Countries citizens as regards job offers made within a member Country. A member Country that renounces the transitional provisions can in any case

19 See Gazzetta C., La circolazione finalmente libera dei lavoratori neocomunitari, op. cit.; Brollo M., Immigrazione e libertà di circolazione, op. cit. 


\section{Roberta Nunin}

\section{Three years later: Italy and free movement of new EU workers}

avail itself of a safeguard clause provided for by the Accession Treaty (art. 37) according to which it can restore its national restrictive regulations if it should register serious and objective alterations in its labour market (the Commission is the competent authority to decide the acceptable type and duration of such restrictive measure). Of course the right was also provided for new member Countries to apply a mutual safeguard clause, with the possibility to limit freedom of circulation "in the opposite direction", i.e. of EU-15 workers (Slovenia, Hungary and Poland availed themselves of that right). Germany and Austria, in keeping with their restrictive approach, asked for a special safeguard clause that - for a few sensitive sectors (building, industrial cleaning) - allowed to limit the supply of services involving temporary transfer of workers employed by companies based in new member States (to be invoked however only in case of serious problems in those sectors).

With regard to the scope of application, we stress that limitations were only provided for in the case of subordinate work, whilst new EU citizens were immediately free to carry out, without authorization, any self-employed work (in Italy, for example, also in the case of the so called "contract project work" (contratto di lavoro a progetto), introduced by Italian legislative decree No. 276/2003). The above mentioned limitations could thus be eluded by foreign workforce supplied in Italy by placement agencies based in new member countries, by work and service tenders using workforce from new European countries, and by the so called transnational posting of workers we shall deal with later.

There is an exception to the moratorium applied to new EU citizens who are legally employed in one of the EU-15 Countries at the date of their Country joining and are admitted to that country labour market for a continuous period of no less that twelve months, or who carried out a work activity in a EU-15 Country after such date for the same period of time: the spouse and children less than 21 years of age, or dependent children, who are legally staying with the worker from a new European country also enjoy this right; in this case, the worker can directly access the labour market of the member Country, but not automatically that of other member States that chose to apply restrictive measures.

Two years after ten new members joined the European Community, the Commission Report dated 8 February 2006 certainly appears to be the key text 


\section{Three years later: Italy and free movement of new EU workers}

to help analyze the effects of the 2004 enlargement ${ }^{\mathbf{2 0}}$. The statistics supplied by the member Countries indicate that the flows of workers from the East were lower than expected, and that no direct link was found between the magnitude of migratory flows and the transitional provisions in force; on the contrary, a beneficial "stabilization" effect was registered on the European labour market ${ }^{\mathbf{2 1}}$; quite significant appears to be the fact that Countries that did not apply restrictions registered a strong economic growth, a drop in unemployment and an increase in employment rates. On the other hand, the restrictions imposed by several countries, including Italy, forced sometimes workers from new EU countries into pockets of illegal work (a phenomenon presenting in Italy some rather worrying aspects), or alternatively caused their entry disguised as transfer workers or independent workers.

As it is known, in Italy the road for these workers has been uphill until 1 January 2007, though mitigated somehow by the provision of entry quotas "distinct" from those applied to non-European workers, with the extra provision of a few procedural simplifications (the employer was exempted from the obligation to supply housing and demonstrate he had adequate economic resources to pay for wages and welfare contributions; as for the workers, the need for an entry visa was cancelled). For a few special categories "extra quota" entries were also provided for. However, against an anticipated quota for 2005 of 79,500 new EU workers, the number of actual entries was only 18,000: quite an opposite trend, therefore, compared with the fears of possible "invasions" 22.

The impact of the moratorium showed its effects (mostly on the negative side) in particular on the Italian north-eastern region of Friuli Venezia Giulia, the only region bordering with a new member State (Slovenia). If it is true that the enlargement process triggered off in Friuli Venezia Giulia a limited occupational crisis (in particular in the clearing agents sector), it is also true that such crisis was satisfactorily handled by the region authorities with special instruments aimed at protecting workers who had lost a job. On the other hand, the moratorium was certainly an obstacle to the significant cross-border mobility (in particular with Slovenia), long present in the Region. The internationalization of labour market in this particular "border" situation appears therefore to be a

20 European Commission, Report on the Functioning of the Transitional Arrangements set out in 2003 Accession Treaty (period 1 May 2004 - 30 April 2006), COM(2006) 48 final, Brussels, 8 February 2006.

21 Parker, Bruxelles study say EU growth benefits all members, in Financial Times, 2 maggio 2006.

22 The expected quota for 2006 was of 170,000 entries. 


\section{Roberta Nunin}

\section{Three years later: Italy and free movement of new EU workers}

resource for development and as such is also judged by the recent Friuli Venezia Giulia regional law No. $18 / 2005^{\mathbf{2 3}}$ on labour. Cross-border collaboration is one of the most supported objectives of the Friuli Venezia Giulia Region at institutional level; also in line with the provisions of the above mentioned regional law No. 18/2005, many agreements and cooperation projects have already been presented and brought forward with new member Countries, for example the proposal to constitute a Euroregion. It is not by chance therefore that the decision of the (new) Italian government, adopted in July 2006, to forfeit the moratorium, was welcomed in this Region by a general sigh of relief.

4. On 1 January 2007 the enlargement process reached a new phase, with the entry of Romania and Bulgaria into the European Community. As for all previous enlargements - and in particular the previous one, on 1 May 2004 - the provision was made for existing member Countries to avail themselves of a transitional period during which they could limit the right of free circulation on their territory for citizens of new member Countries.

As regards the entry into Italy of Rumanian and Bulgarian citizens, we must first of all remember that from 1 January 2007 no longer apply to them the provisions of Italian legislative decree No. 286/98 (and further amendments and additions) but rather those of Italian presidential decree No. 54 dated 18 January 2002 (Consolidated law on circulation and establishment of citizens from the European Community Member States) and further modifications. These last provisions include among other things: a) free entry into the State territory for citizens of member States that are required to hold an identification document, valid according to the State national law; b) freedom of establishment in the national territory for up to three months (for longer periods they must hold a residence permit); c) possibility to carry out a work activity on a self-employed basis, to supply services or to be recipients of services; d) possibility to attend, as students, accredited schools or universities; e) right to establishment - without a residence permit - allowing workers to carry out subordinate work for no longer than three months, certified by the employer, or a seasonal subordinate work; f) right to family reunion; g) issue of a residence permit (valid for five years), by the competent police office within one hundred and twenty days following application, pending the cancellation

23 "Norme regionali per l'occupazione, la tutela e la qualità del lavoro". See also Brollo M. Le competenze legislative della Regione Friuli Venezia Giulia in materia di lavoro alla luce delle recenti riforme, in Regione Friuli Venezia Giulia, II mercato del lavoro nel Friuli Venezia Giulia, Rapporto 2005, 2006, 37; Merzliak S., Economia e Lavoro nella Regione Friuli Venezia Giulia nel periodo 2001-2004, ibidem, 49. 
of the need for such document as provided for by the 2004 directive, whose implementation procedure in Italy is about to be completed while we are writing this paper. It is also stated that a European citizen may be asked to leave only for reasons of public policy, public security or public health ${ }^{\mathbf{2 4}}$.

The above mentioned new EU citizens can therefore freely enter Italy and can, if they have the requisites mentioned in Italian presidential decree No. $54 / 2002$, apply to the competent police office for a residence permit (pending the current implementation of the 2004 directive), directly or through a post office (see on the subject the Circular from the Italian Home Office Ministry and the Welfare Ministry dated 28 December 2006, No. 2). With regard to labour market access, as already happened in 2004, Italy decided to avail itself of a transitional period - this time of one year duration - before fully liberalizing access to subordinate work for Rumanian and Bulgarian citizens. Although enjoying European citizen status, the latter may therefore see their freedom of circulation limited due to work reasons, or rather - we should say - due to subordinate work reasons, whilst access to self-employed work is free, as we already mentioned. Unlike what happened in 2004, this time the choice by Italy of a transitional period was only partial and selective, and does not cover all work sectors.

Our country - also in view of the needs expressed by the business and industrial world (that had quite unfavourably received the 2004 moratorium) decided that the freedom of circulation for Rumanian and Bulgarian citizens in order to access subordinate work could be immediately without limitations in a number of sectors: agriculture and tourist-hotel industry; domestic work and person care; building; engineering; seasonal work; managerial and highly qualified work. In the above listed sectors the opening of the (subordinate) labour market to new EU citizens must be seen therefore as in full force starting on 1 January 2007. For all remaining production sectors, a simplified recruiting procedure can in any case be used, if the employer applies for authorization (by mailing a registered letter with advice of receipt) to the competent immigration One Stop Shop using the proper forms available from the Home Office (www.interno.it) and Welfare Ministry (www.welfare.gov.it) websites.

With the joint Circular dated 3 January 2007, No. 3, the two Italian Ministries deemed appropriate to provide some indications to help interpret the Circular (also in relation to any "pending" entry application), pointing out straight away that

24 See Galantino L., Diritto comunitario del lavoro, op. cit.; Roccella M. - Treu T., Diritto del lavoro della Comunità Europea, op. cit.; Arrigo G., II diritto del lavoro dell'Unione Europea, cit. 


\section{Roberta Nunin}

\section{Three years later: Italy and free movement of new EU workers}

recruitment in "privileged" sectors can take place immediately without any formality (in these sectors any entry application to the One Stop Shop dealing with the p.m. decree on migratory flows dated 15.02.2006 is to be dismissed), provided that Italian law provisions on the subject of communications to Employment Centres and competent health and welfare bodies are complied with. Recruitment in "non privileged" sectors however still requires the employers to apply for authorization to the immigration office (in this case any application made in connection with the 2006 migratory flows decree will be transferred from One Stop Shop to the "simplified" procedure); the application will then be transmitted to the Provincial Labour Directorate to check the compliance with minimum requirements set by the implemented National Collective Agreement, without checking the employer's economic capacity nor the stipulation of the residence contract. Once the authorization is granted, the worker shall not have to ask for an entry permit, but can just apply to the competent police office for a residence permit, directly or through a post office.

After summing up the procedural aspects, we can imagine that some application problem may arise in identifying the exact "extent" of privileged sectors, on which - apart from listing them - nothing is said: for example, is it to be assumed that the Collective Agreement applied by the employer is "exhaustive" in identifying the sector? Or are further specifying elements required? ${ }^{\mathbf{2 5}}$ Fortunately enough, the limited duration of the transitional period (one year) minimizes at least in part possible interpretation problems.

5. Other, and different issues are involved in the case of workers posting ${ }^{\mathbf{2 6}}$. The inclusion of foreign workers posting in Italy into what might be called "transnational tenders" leads us to make a few brief considerations on this

25 See Villanova V., Lavoratori bulgari e romeni: cosa cambia dopo l'ingresso nell'Ue, in Guida al Lavoro, 2007, 3, 21.

26 See Cinelli M., Distacco e previdenza nella prestazione transnazionale di servizi, in II Lavoro nella giurisprudenza, 2007, 2, 124; Lyon Caen A., Le travail dans le cadre de la prestation internazionale de services, quelques observations, in Droit sociale, 2005, 503; M.T. Carinci, Le delocalizzazioni produttive in Italia: problemi di diritto del lavoro, working paper of the "Massimo D'Antona" Study Center on Labour Law - Catania, 2006, www.lex.unict.it/eurolabor/ricerca; Foglia R., Il distacco del lavoratore nell'Unione Europea: la normativa comunitaria, in Massimario di Giurisprudenza del lavoro, 2001, 806; Massi E., II distacco dei lavoratori in ambito europeo, in Diritto e pratica del lavoro, 2000, 22, 1565; Orlandini G., la disciplina comunitaria del distacco dei lavoratori fra libera prestazione $d i$ servizi e tutela della concorrenza: incoerenze e contraddizioni nella direttiva $n .71$ del 1996, in Argomenti di diritto del lavoro, 1999, 465; Balandi G., La direttiva comunitaria sul distacco dei lavoratori: un passo avanti verso il diritto comunitario del lavoro, in Quaderni di diritto del lavoro e relazioni industriali, Torino, Utet, 1998, 20, 115; Davies P., Posted workers: single market or protection of national labour law system?, in Common Market Law Review, 1997, 571. 


\section{Three years later: Italy and free movement of new EU workers}

increasingly widespread phenomenon - a sort of "delocalization in reverse" involving, instead of the move abroad of businesses, the move to Italy - through service tender or posting - of foreign workers (who may be European or non-European) employed by foreign companies (European or non-European).

I shall not dwell here on the issue of entry of non-European citizens, as the subject I wish to tackle is that of rights and protections for workers involved in this form of transnational mobility, now increasingly widespread also in Italy.

I think it would be interesting in the first place to look at the so called "international posting of workers", identified as such when the parties concerned (posting/posted) have a different nationality or, for example, when the contract was made abroad, or when the place where the work/service is carried out is situated in a foreign state (with respect to the state where the contract was stipulated). In these cases, as we are going to see, it appears necessary to tackle beforehand the problem of jurisdiction, governed in Italy by law No. 218/1995 (Reform of Italy international private law) following indications of the 1968 Brussels Convention which states, basically, that in case of an "individual work contract" the judge of the place where the worker habitually carries out his activity has jurisdiction over the matter.

Of key relevance, for the aspects we are interested in, is the question of applicable law in such work relationships. If the relationship is characterized by such elements of internationality, what law is actually to be applied to a foreign worker posted to Italy?

We must recall art. 6 of the well known Rome Convention, dated 19 June 1980, on the law to be applied to contract obligations; this offers for work contracts a choice of applicable law by the parties - according to the guiding principle of the Convention: in the absence of choice, cannot deny workers the protection ensured by the binding regulations of the law governing the contract, according to paragraph 2, the latter stating that in the absence of choice the employment contract shall be governed: a) by the law of the country in which the employee habitually carries out his work in performance of the contract, even if he is temporarily employed in another country, or $b$ ) if the employee does not habitually carry out his work in any one country, by the law of the country in which the place of business through which he was engaged is situated, unless it appears from the circumstances as a whole that the contract is more closely connected with another country, in which case the contract shall be governed by the law of that country. 


\section{Roberta Nunin}

\section{Three years later: Italy and free movement of new EU workers}

In essence, as we can see, the principle of the most favourable treatment for the worker is applied here. The implementation of the Rome Convention may lead to the foreign worker being recognized the right to the same treatment enjoyed by Italian workers, at least as an application of the international public order principle (see art. 16 of the Rome Convention).

On the other hand the (little) case law dealing with the subject does not fail to point out that the provisions quoted, aimed at avoiding social dumping, are in actual fact often not complied with, thus making it profitable for an Italian company to resort to these forms of "delocalization in reverse" ${ }^{\mathbf{2 7}}$.

We must also highlight the reference to habituality (... place where the worker habitually carries out his work...); we believe that this allows to exclude the case when a worker is engaged only occasionally abroad (i.e. when posting is of little or very little importance as far as time is concerned): in this case, if the contract parties did not mention any governing law, the relationship is to be intended as governed by the law of the place where the worker habitually carries out his work (usually - although not necessarily - to be identified with the law of his country of origin). In these cases, if there is no "habituality" in carrying out the work in Italy, the binding regulations of Italian law cannot be applied. A "flaw" therefore emerges in the protection of foreign workers sent temporarily to work in Italy (as in fact usually happens in the case of posting).

That's the reason why we must now underline the point made - although with the already mentioned limitations and only for the examined cases - by Italian legislative decree No. 72/2000, which implemented directive No. 71/96, in relation to posting as part of transnational services supply. In this specific case the above mentioned limitations can be overcome, as the adopted definition already highlights specifically the work's temporary nature in defining the notion of "posted worker". The above regulations set out a number of rights/guarantees for the worker sent to Italy by a foreign company (even, notice, a non-European one, according to the provisions of the implementing Italian law: see art. 1, paragraph.3, of legislative decree No. 72/2000) to supply a service or be on duty at a production unit of the same company or at another company belonging to the same group (note, in this regard, that the case of posting from a foreign company to an Italian company, not involving corporate groups, is not covered).

27 M.T. Carinci, Le delocalizzazioni produttive in Italia: problemi di diritto del lavoro, op. cit. 


\section{Three years later: Italy and free movement of new EU workers}

These rights are identified as follows: 1) the right to benefit from the same work conditions provided for by legislative, regulatory or administrative regulations, as well as collective agreements approved by the most represented trade unions at national level, enjoyed by workers who carry out a comparable subordinate work in Italy, on the place where the work/service is supplied (although with some exceptions provided for by art. 3, paragraph. 2 of legislative decree No. 72/2000); 2) in case of contracts for services to be supplied "within" Italian companies the law indicates a joint and several liability of contracting and contractor companies for the treatment due to workers (art. 3, paragraph 3); 3) workers rights can be exercised with regard to the contracting company no later than one year after contract termination (art. 3, paragraph 4).

A "minimum protection" core therefore emerges from the European directive, provided of course that the favor principle is fully operational, to be applied in the case of:

- posting of workers employed by a company of one member state to the territory of another member state as part of a contract stipulated between the company that posts the worker and the recipient of services;

- posting of workers employed by a company of one member state to another company of the same group, operating in the territory of another member state;

- posting of workers employed by temporary staff placement agencies of any one member state to a client with registered office or main place of business in another member state.

In Italy however, during the implementation stage, legislative decree No. $72 / 2000$ extended the application of such regulations to companies established in non-member states that meet the above mentioned conditions (art. 1, paragraph 3).

We already showed the conditions guaranteed to these workers. Protection rules refer in particular to condition s provided for by legislative, regulatory or administrative provisions, as well as collective agreements stipulated by the most represented trade unions at national level, applied to workers carrying out similar work in the place where posted workers conduct their activity, including:

- maximum working periods and minimum resting periods duration;

- minimum duration of annual paid holidays (this provision does not apply to the initial assembly and/or installation work in a goods supply contract, essential to put into operation the supplied good and carried out by 


\section{Roberta Nunin}

\section{Three years later: Italy and free movement of new EU workers}

qualified and/or specialized workers of the supplying company, when the duration of the work for which posting is required does not exceed eight days);

- $\quad$ minimum wages, including overtime (also subject to the above mentioned derogation);

- $\quad$ safety, hygiene, work health, protection of pregnant female workers, equal treatment for men and women, and discrimination ban.

I shall lastly recall that posting of non-European workers employed by companies based abroad and assigned to carry out subordinate work in Italy at branches of the same company or at Italian companies is governed by art. 27 paragraph (i) of legislative decree No. 286/1998, expressly referring to the application of art. 1655 of the Italian Civil Code on tenders, as well as by international and European regulations.

With special reference to welfare issues ${ }^{\mathbf{2 8}}$, on the question of posting of workers within the European Community, we must lastly mention the quite relevant provisions of art. 14 of EEC regulation No. 1408/71 (recently ruled to be cancelled by regulation No. 883/2004, which retains however its basic principles): with an exceptional decision as regards the territoriality principle, this grants (granted) the right to keep the insurance regime (health and welfare) of the Country of origin for twelve months (extended for another twelve upon authorization of the host Country) to workers who are member States citizens. Such right (to evade the territoriality principle, that's to say "national security contributions are paid in the State where one works") no longer applies when the worker remains beyond the maximum allowed posting period (defined by international agreements), with the consequent subjection to the social security system of the country where the work is carried out.

I shall also point out that art. 17 of the same regulation states that member States in special cases can grant further exceptions to the territoriality principle as regards insurance obligations ${ }^{29}$. We must recall that, in order to prevent an illegitimate use of posting within the European Community, decision No. 162 (1996) of the EC administrative Commission on the safety of migrant workers - now merged into decision No. 181 (2000) - stressed the

28 See Cinelli M., Distacco e previdenza nella prestazione transnazionale di servizi, op. cit.; Allamprese A., Distacco dei lavoratori stranieri in Italia nel quadro di una prestazione transnazionale di servizi: profili previdenziali, in Previdenza e assistenza pubblica e privata, 2006, 1; Maretti S., La legislazione previdenziale applicabile ai lavoratori temporanei distaccati all'estero, in Massimario di giurisprudenza del lavoro, 2000, 538;

29 See also, to frame the issue, the INPS (Istituto Italiano della Previdenza Sociale) circular dated 21 February 2005, No. 33, and the INPS message dated 29 March 2005, with enclosed a useful "working manual" on posting. 
Three years later: Italy and free movement of new EU workers

need, to properly identify posting, for a careful check on the existence of organic links between worker and posting company, indicating a number of elements to be taken into consideration to that end: responsibility in recruiting, stipulation and managing of the work contract, setting out of work conditions, and entitlement to terminate the working relationship; again in order to avoid abuse, it was also provided for that any temporary work interruption during the period of posting (due to holidays, illness, etc.) shall not entail a work interruption such as to justify an extension of the same duration in the work activity.

In conclusion, to wind up what has been said, we can underline the following points:

1. general international laws on obligations in these cases do not prevent the application of binding regulations of the country more connected with the work relationship, nor the possibility to extend the legislation of one state to the person in any way employed, even temporarily, on its territory;

2. in this context, the Community directive on posting as part of service supply intervened to create a central core of protection rules, however flexible and open to exceptions in the presence of certain conditions (e.g. posting not exceeding 8 days)

3. the directive in question does not dictate any principle on the subject of social security: the provisions set by EEC Regulation No. 1408/71 (and further amendments) or by international Conventions with non-European countries are therefore still applicable.

Finally, the crux of the matter rests in avoiding that transnational tenders or posting legislation may become an escape route in order to curb costs, thus altering the competition system balance. It then appears necessary not only to further harmonize the different labour systems, but also to heed the call from Community institutions for a check, in posting cases, of the organic links between worker and posting company, sometimes difficult to perform: such difficulties cannot be overcome without an adequate cooperation between the administrations of different EU member countries; as we are dealing with checks on the compliance of work conditions, I shall just recall on closing that the EU Court of Justice underlined the importance of administrative cooperation with a well know ruling dated 23 November 1999 (in the merged C-369/96 and C-376/96 cases) where, with reference to the building industry, the Court judged that for an effective protection of workers in the building sector it may be necessary to keep certain documents available in the yard - or at least, in a clearly identified place situated in the host country, accessible to State authori- 


\section{Roberta Nunin}

\section{Three years later: Italy and free movement of new EU workers}

ties - in order to carry out the checks, in particular when there is not an organized system of cooperation and exchange of information between member States.

6. It is well known that a European social protection system for workers moving within different member Countries is judged in the original Treaty as strictly linked to the workers free circulation; I already stressed however that the most recent developments of Community law quite rightly opened up to the recognition of an independent role for such rights, as part of the slow evolution of the "European social citizenship" concept.

In the sectors that are not its exclusive competence (such as social security) European authority intervenes with respect to the principle of subsidiarity, that is, according to art. 5.2 of the Treaty, only and in so far as the objectives of the action provided for cannot adequately be achieved by member States and might therefore, because of the size or effects of the action in question, be better achieved at European level. Incidentally, I must remind that, together with the subsidiarity principle, the Treaty also sanctions the principle of proportionality, whereby Community measures (either exclusive or subsidiary) must not go beyond what is necessary in order to achieve the objectives provided for by the Treaty (art. 5.3). The application of the subsidiarity principle - we should rather call it a technique for regulating European competences ${ }^{\mathbf{3 0}}$ - has taken place gradually in the context of an accelerating integration process and expansion of European policies intervention ${ }^{\mathbf{3 1}}$. The jurisprudence, on its part, saw immediately the criterion's remarkable potentials, conferring it a dynamic, flexible and pragmatic character ${ }^{\mathbf{3 2}}$. Most current definitions, in this respect, do not fail to underline the notion's compromizing character, trying to reconcile the need for European integration with the necessary protection of different national traditions ${ }^{\mathbf{3 3}}$.

30 Tosi P. - Lunardon F., Introduzione al diritto del lavoro. 2. L'ordinamento europeo, op. cit., 137.

31 See Arrigo G., Principio di sussidiarietà e politica sociale, in Lavoro e diritto, 1995, 479.

32Tosi P. - Lunardon F., Introduzione al diritto, op. cit., 138: "definizioni spicciole si contendono tuttora il campo con definizioni più attente e raffinate; definizioni politiche con definizioni tecniche; critiche con plausi» (op. cit.).

33 See Tosi P. - Lunardon F., Introduzione al diritto, op. cit., 138; D'Antona M., Chi ha paura della sussidiarietà?, in Lavoro e diritto, 1994, 565; Galantino L., Diritto comunitario del lavoro, op. cit., 15: «il disegno complessivo del principio di sussidiarietà è (...) quello di valorizzare non solo il livello nazionale rispetto a quello comunitario, ma anche e soprattutto il livello locale di rappresentanza e di governo, cioè le regioni». 


\section{Three years later: Italy and free movement of new EU workers}

In the fields assigned in primis to member States authority, such as social security - the application of the principles outlined above becomes therefore a dominant theme, also related to another fundamental principle of the Treaty, such as the principle of non discrimination based on nationality (art. 12). It is quite apparent that the diversity of social security systems within member Countries can lead to inequality of treatment, in particular for migrant workers who can be subject to a different legal system than in their State of residence. The principle of non discrimination thus becomes a fundamental principle even on matters - like social security - that remain the competence of member Countries; art. 137 of the Treaty grants however the Council faculty to adopt measures aimed at encouraging the cooperation between member Countries and issue directives on minimum applicable provisions, taking into account the technical regulations in force in each member State, without affecting the right recognized to each member State to define the fundamental principles of its own social security system, nor significantly compromizing the State finances.

The evolution of the European system in social security matters still excludes harmonization at the moment (see art. 137, paragraph. 2), being limited to provisions for "coordination"; art. 42, after recent modifications to the Treaties, was kept, but is now found not under Heading IX - devoted as we know to social policies - but under Heading III, paragraph I, indexed under free circulation of people (and in particular workers). While we agree that European intervention on social security issues is now more incisively structured compared to the past (when it was strictly and instrumentally oriented to attain a single market), it is also true that its scope of intervention was reassessed, going from the objective of harmonization to a softer one of coordination and promotion $^{\mathbf{3 4}}$.

The ensuing legislation on the coordination of social security issues was brought into effect with a series of Regulations, among which of key importance is Regulation No. 1408/71 dated 14 June 1971, modified several times and now waiting to be cancelled by Regulation No. 883/2004 dated 29 April 2004, when the implementation rules will be adopted.

In the light of what we reported above, i.e. the fact that a European regulatory system, having a coordinating and not harmonizing function, leaves member Countries free to decide about the type and number of insured peo-

\footnotetext{
${ }^{34}$ See Cinelli M., Appunti in tema di incidenza del diritto comunitario sull'ordinamento interno in tema di sicurezza sociale, in Diritto delle relazioni industriali, 2000, 1, 96; Borelli S., Tra libera circolazione e sicurezza sociale: chi sono i soggetti tutelati?, in Lavoro e diritto, 2001, 4, 627; Cardoni, Libera circolazione dei lavoratori e sicurezza sociale nella Comunità europea, Padova, Cedam, 2002.
} 


\section{Roberta Nunin}

\section{Three years later: Italy and free movement of new EU workers}

ple, the services provided (and the conditions in order to access them), the financing systems, etc., European authority can nevertheless intervene with a minimum number of regulations, binding for all member States, inspired by the principle of non discrimination and aimed at neutralizing the effects of the territoriality principle in national laws, to ensure in practice the free circulation of workers. European Community law on the subject is inspired by the following principles:

1. the principle of territoriality, providing for the application of the law of one member State, which is the one where the working activity is carried out, even if the worker resides in another member State (with a few exceptions in case of posting and temporary workers);

2. the principle of non-discrimination, according to which people who reside in the territory of a member State are admitted to benefit from the laws of the member State where they work at the same conditions enjoyed by the citizens of that State (excluding any form of discrimination, either direct or involving their relatives and/or survivors whom the Court of Justice recognized to be entitled not only to secondary rights, but also to jure proprio rights);

3. the principle of exportability of services, whereby social security benefits acquired according to the law of one or more member states cannot be subject to reduction, modification, suppression or confiscation because the owner resides in the territory of a member State different from the one where the debtor institution is located (although that applies to financial benefits, while it is not possible to "export" benefits in kind, for which the law of the State where the competent institution is located only defines the right to, whilst outpayment modalities are defined by the State of residence, even when the competent institution is the only debtor);

4. the principle of cumulative insurance periods, according to which the institution competent for outpayment in any one member State must take into account, as necessary, the periods of insurance or occupation covered by the law of any other member State, as if they were periods covered by its own State legislation.

The new No. 883/2004 Regulation confirms the principles outlined above - in time updated and further specified by the Court of Justice case law - and reaffirms that there is no justification in principle within the Community to make social security rights subject to the place of residence of any individual 
entitled to social security benefits: in light of the fact that coordinating measures may not be adequately implemented by member States, it also confirms that the Community can intervene, in line with the already mentioned principles of subsidiarity and proportionality. It also reaffirms the role of collaboration and mutual commitment to information and cooperation between competent institutions of member States, it being understood that the individual concerned must inform both the authorities of the member State where he resides and those of the member State competent to deal with any change in his personal situation.

As for applying such corpus of regulations to new European workers (those involved in the 2004 enlargement as well as in the very recent 2007 enlargement), I shall mention that the Accession Act provision for the application of European law involves in this regard the suspension of all previous bilateral agreements (for example, between Italy and Slovenia there was a recent Convention signed in 1997, ratified by law No. 199 in 1999 and came into effect on 1 August 2002 which on 1 May 2004 was suspended with the consequent application, after that date, of European law).

We can see that on the subject of social security we do not find the problems we had to take into consideration for free circulation (e.g. the choice of some Countries to apply full or partial moratorium): the reason being that a situation had come about - and in some countries still persists (for the new 2007 members in Italy too, to some extent) - whereby workers from new member States are (or were) considered in several Countries as non-European in so far as access to the labour market of old member States was involved (although with different approaches), while there is (was) no impediment to the applicability of European provisions on social security. Such situation - as I mentioned above - was recently overcome by Italy for the new 2004 member Countries, following the notification on 27 July 2006 by the Italian Government to the Commission of its intention to renounce a transitional period for the free circulation of workers from the eight States of the European Union for whom in 2004 a choice had been made in favour of a moratorium - however now reproposed for (part of) Bulgarian and Rumanian workers, for whom the choice made, as illustrated above, was this time one of "selective" moratorium with respect to the freedom of circulation.

The experience of a (former) border region, as in Italy is Friuli Venezia Giulia that can be considered a true "laboratory" of the new (enlarged) Europe shows that an effective, legal set of regulations governing the European system of social rights for new Member States also needs, in order to be really functional, a number of integrated actions and opportunities for 


\section{Roberta Nunin}

\section{Three years later: Italy and free movement of new EU workers}

knowledge and collaboration promoted in particular by institutional and social bodies operating on the territory that, after a phase of surveying needs and expectations, will operate to concretely realize the process of European social integration for new EU workers. In this view, quite interesting are for example, on the subject of welfare rights, the projects brought forward by Italian welfare institutions in collaboration with their counterparts in new member Countries, such as the "Protection with no frontiers" project ("Tutela senza frontiere") that led in 2005 to the signing of a Protocol between the Italian INAIL (Istituto nazionale per l'assicurazione contro gli infortuni sul lavoro) and ANMIL (Associazione nazionale mutilati e invalidi del lavorol in the Gorizia province and the Slovenian Work Invalids Association ${ }^{\mathbf{3 5}}$, to gather indications, organize exchange of information and monitor the main problems emerging for the partners involved.

Prof. dr. Roberta Nunin je predavateljica delovnega prava na tržaški univerzi in nosilka dodiplomskih predmetov Evropsko delovno pravo na Pravni fakulteti ter Primerjalnega delavnega prava na Filozofski fakulteti Univerzev Trstu. Od leta 2001 aktivno sodeluje pri izvedbi podiplomskih magistrskih programov s področja delovnega prava in socialne varnosti. Od leta 1999 je članica uredniškega odbora priznane mednarodne revije Italian Labour Law e-Journal. Je avtorica več kot 80 člankov, študij in samostojnih del $v$ različnih publikacijah. Njene študije so usmerjene predvsem na področje evropskega socialnega dialoga, delovnega prava in diskriminacije, otroškega dela, nasilja na delovnem mestu ter varstva in varnosti pri delu.

35 See La Bella C., Tutela senza frontiere - Integrazione sociale e assicurazione infortuni sul lavoro dopo I'allargamento ad Est dell'Unione Europea: nuove tematiche e prospettive emergenti sul territorio goriziano e sloveno, in INAIL-Istituto Nazionale per I'assicurazione contro gli infortuni sul lavoro, Rapporto Annuale Regionale 2005 - Friuli Venezia Giulia. 


\section{Three years later: Italy and free movement of new EU workers}

\section{Bibliography}

- Arrigo, G. (1998): II diritto del lavoro dell'Unione Europea, vol. I, Milano, Giuffrè.

- Arrigo, G. (1995): Principio di sussidiarietà e politica sociale, in Lavoro e diritto.

- Balandi, G. (1998): La direttiva comunitaria sul distacco dei lavoratori: un passo avanti verso il diritto comunitario del lavoro, in Quaderni di diritto del lavoro e relazioni industriali, Torino, Utet.

- Blanpain, R. (2006): European Labour Law, The Hague, Kluwer Law Int. (30th ed.).

- Borelli, S. (2001): Tra libera circolazione e sicurezza sociale: chi sono i soggetti tutelati?, in Lavoro e diritto.

- Brollo, M. (2006): Immigrazione e libertà di circolazione, in II Lavoro nella giurisprudenza.

- Cinelli, M. (2000): Appunti in tema di incidenza del diritto comunitario sull'ordinamento interno in tema di sicurezza sociale, in Diritto delle relazioni industriali.

- Cinelli, M. (2007): Distacco e previdenza nella prestazione transnazionale di servizi, in II Lavoro nella giurisprudenza.

- Carinci, M., T. (2006): Le delocalizzazioni produttive in Italia: problemi di diritto del lavoro, working paper of the "Massimo D'Antona" Study Center on Labour Law Catania, www.lex.unict.it/eurolabor/ricerca.

Davies, P.(1997): Posted workers: single market or protection of national labour law system?, in Common Market Law Review.

- Foglia R. (1999): L'applicazione giurisprudenziale del regolamento CEE n. 1408/71, in II Diritto del lavoro, II.

- Foglia, R. (2001): Il distacco del lavoratore nell'Unione Europea: la normativa comunitaria, in Massimario di Giurisprudenza del lavoro.

- Galantino, L. (2005): Diritto comunitario del lavoro, Torino, Giappichelli.

- Giubboni, S. (1998): Libertà di circolazione e protezione sociale nell'Unione Europea, in Giornale di Diritto del lavoro e relazioni industriali.

- Lyon, Caen A. (2005): Le travail dans le cadre de la prestation internazionale de services, quelques observations, in Droit sociale.

- Maretti, S. (2000): La legislazione previdenziale applicabile ai lavoratori temporanei distaccati all'estero, in Massimario di giurisprudenza del lavoro.

- Massi, E. (2000): II distacco dei lavoratori in ambito europeo, in Diritto e pratica del lavoro.

- Nascimbene, B. (1998): La libera circolazione dei lavoratori, Milano, Giuffrè. 


\section{Roberta Nunin}

\section{Three years later: Italy and free movement of new EU workers}

- Orlandini, G. (1996, 1999): La disciplina comunitaria del distacco dei lavoratori fra libera prestazione di servizi e tutela della concorrenza: incoerenze e contraddizioni nella direttiva n. 71 del 1996, in Argomenti di diritto del lavoro.

- Padoa-Schioppa, T.(2006): L'Europa della malinconia, lecture held at University Bocconi of Milan, Inauguration of academic year 2005/2006.

- Roccella, M., Treu T. (2002): Diritto del lavoro della Comunità europea, Padova, Cedam.

- Roccella, M.(1997): L'Europa e L'Italia: libera circolazione dei lavoratori e parità di trattamento trent'anni dopo, in Rivista Giuridica del lavoro e della previdenza sociale.

- Schulten, T. (2006): Minimum wages in Europe, in Transfer-European Review of Labour and Research.

- Shi, L. (2005): Does Oversight Reduce Policing? Evidence from the Cincinnati Police Department After the April 2001 Riot, SSRN Working Paper.

- Schulten T., Bispinck R., Schäfer C. (2006), Minimum wages in Europe, Brussels, ETUI.

- Tosi P., Lunardon F., (2005): Introduzione al diritto del lavoro. 2. L'ordinamento europeo, Roma-Bari, Laterza.

- INPS (Istituto Italiano della Previdenza Sociale) circular dated 21 February 2005, No. 33, and the INPS message dated 29 March 2005, with enclosed a useful "working manual" on posting.

- European Commission, Report on the Functioning of the Transitional Arrangements set out in 2003 Accession Treaty (period 1 May 2004 - 30 April 2006), COM (2006) 48 final, Brussels, 8 February 2006. 


\section{POVZETEK}

\section{TRI LETA KASNEJE: ITALIJA IN PROSTO GIBANJE DELAVCEV IZ NOVIH DRŽAV ČLANIC EU}

Prosto gibanje delavcev, kot eden izmed glavnih štirih stebrov EU, se lahko definira kot nevtralno načelo, ki zagotavlja svojo uporabo tako na ekonomskem področju, kjer je bilo ustvarjeno, kot tudi na socialnem področju. Prispevek se osredotoča na odziv Italije glede uporabe tega načela pri zadnjih dveh širitvah EU v letih 2004 in 2007. Ta pravica zagotavlja prosto gibanje delavcev, vključuje odpravo vsakršne diskriminacije na podlagi državljanstva delavcev držav članic v zvezi z zaposlitvijo, plačilom in drugimi delovnimi in zaposlitvenimi pogoji. Delavec se lahko na območju držav članic prosto giblje, biva $v$ državi članici $v$ času zaposlitve in ostane na ozemlju države članice tudi po prenehanju zaposlitve $v$ tej državi pod pogoji, zajetimi v izvedbenih predpisih, ki jih pripravi Komisija.

Če so bili evropski predpisi na koncu pedesetih let prejšnjega stoletja zasnovani tako, da so italijanskim delavcem omogočili migracije na ozemlje ostalih petih članic skupnosti, so se skozi leta in desetletja migracijski tokovi drastično spremenili, medtem ko so predpisi ostali nespremenjeni. Širitev EU z novimi članicami z vzhoda Evrope, z rastjo prebivalstva iz neevropskih držav, je povečala problem nadzora nad migracijskimi tokovi ter skrbi starih držav članic pred prevelikim naseljevanjem delavcev z novih držav članic, kar je celo povzročilo zavrnitev Pogodbe o Ustavi za Evropo s strani dveh držav ustanoviteljic skupnosti - Francije in Nizozemske.

Tri leta kasneje je jasno, da so bile skrbi pred masovnim priseljevanjem - vsaj kar zadeva stanje v Italiji - neutemeljene; nekatere nove države članice so bile celo zaskrbljene nad t. i. "begom možganov" ter problemi nizke rodnosti in vse večjega dela stare populacije. Dve leti zatem, ko je deset novih članic vstopilo $v$ EU, je bilo poročilo Komisije $z$ dne 8. februarja 2006 ključni tekst pri analizi učinkov širitve iz leta 2004. Na podlagi statističnih podatkov, ki so jih posredovale države članice, je bilo ugotovljeno, da so tokovi delavcev iz Vzhoda nižji od pričakovanih. Našli niso tudi nobene neposredne povezave med velikostjo migracijskih tokov in prehodnimi veljavnimi predpisi. Ravno nasprotno - na evropskem trgu delovne sile je bil ugotovljen koristen stabilizacijski učinek, medtem ko je bilo $v$ nekaterih državah, vključno $z$ Italijo, zaznati povečan obseg dela na črno. Italija je s 1. januarjem 2007 sprostila domači trg delovne sile za 
Roberta Nunin

Three years later: Italy and free movement of new EU workers

delavce držav članic; za zadnji dve novi članici Romunijo in Bolgarijo, ki sta postali članici $z$ istim datumom, velja prosto gibanje na številnih področjih, kmetijstvo, in turistično-gostinske storitve, delo na domu in pomoč osebam, gradbeništvo, inženiring, sezonsko delo, managerska in visoko kvalificirana dela. Za preostala področja se uporablja enostaven postopek izbire, če delodajalec zaprosi za dovoljenje pristojni emigracijski One Stop Shop (načelo "vse na enem mestu") s prošnjo, ki je dostopna na spletnih straneh Ministrstva za notranje zadeve in Ministrstva za socialne zadeve.

Prosto gibanje delavcev je skoraj 40 let urejala Uredba EU, št. 1612/1968, pred kratkim spremenjena z Direktivo št. 38/2004/EC, za omogočanje pravice državljanov Unije in njihovih družinskih članov do prostega gibanja in prebivanja na ozemlju držav članic. Direktiva implementira številne primere, ki so izšli iz sodne prakse Sodišča Evropskih skupnosti. Pravo Evropskih skupnosti v zvezi s prostim gibanjem delavcev sledi: načelu teritorialnosti, ki zagotavlja uporabo prava tiste države članice, kjer se izvršuje delo, čeprav delavec prebiva $v$ drugi državi članici (z nekaterimi izjemami pri začasnih delavcih); načelu nediskriminacije, po katerem je ljudem, ki prebivajo na teritoriju države članice dopustna uporaba beneficij prava tiste države članice, kjer delajo pod enakimi pogoji kot državljani te države; načelu izvozljivosti storitev, kjer koristi iz naslova socialne varnosti ene ali druge države članice ne smejo biti predmet zmanjševanja, sprememb ali zaplemb, ker upnik prebiva na teritoriju države članice, ki je različno od tiste, kjer prebiva dolžnik in načelu kumulativnega zavarovalnega obdobja, kjer mora pristojni organ za dajanje plačil v katerikoli državi članici upoštevati zavarovalna obdobja, ki jih zajema pravo katerekoli druge države članice, kot da bi bilo obdobje vsebovalo $v$ lastni zakonodaji. Nova Uredba št. 883/2004 o koordinaciji sistemov socialne varnosti sledi omenjenim načelom ter sodni praksi Sodišča Evropskih skupnosti in poudarja, da ni nobenega opravičila, da bi vezali pravice iz socialnega zavarovanja na prebivališče posameznika in omogoča intervencijo Skupnosti v okviru načela subsidiarnosti in sorazmernosti. Prav tako poudarja vlogo sodelovanja in medsebojnih zavez med pristojnimi organi držav članic.

Vpliv moratorija je $v$ Italiji pokazal svoje učinke (večinoma negativne) predvsem $v$ severno-vzhodni regiji Furlaniji-Julijski krajini (Friuli-Venezia Giulia) kot edini regiji, ki meji na Slovenijo. Moratorij je bil ovira za mobilnost iz Slovenije, ki je bila pred tem $v$ teh krajih že dolgo prisotna. Internacionalizacija trga delovne sile na tem mejnem območju je vir 
razvoja in mejnega sodelovanja, zato je bila odprava moratorija toliko bolj pozdravljena z obeh strani. Izkušnja nekdanje mejne regije FurlanijeJulijske krajine je lahko pravi laboratorij za novo (razširjeno) Evropo, ki kaže, da lahko učinkovit pravni set regulacij, ki urejajo evropski sistem pravic iz socialne varnosti za nove države članice, potrebuje številne integrirane akcije in priložnosti za znanje ter sodelovanje, ki ga vzpodbujajo organi, ki delujejo na mejnem območju. Italijanska primera sta npr. "Varovanje brez mej" ("Tutela senza frontiere") in ANMIL (Nacionalno združenje pohabljenih in invalidov pri delu - Associazione nazionale mutilati e invalidi del lavoro) s slovensko organizacijo Združenja delovnih invalidov, ki sta pripomogla k zbiranju indikacij, organiziranju izmenjave informacij in spremljanju glavnih težav, ki se pojavljajo na obeh partnerskih straneh. 